\title{
Understanding the Structures and Contents of National Interests: An Analysis of Structural Equation Modeling
}

\author{
Charles Chong-Han Wu
}

\begin{abstract}
Scholars of international relations have consistently applied a single indicator to represent state interests. However, the concept of national interest will be elusive if we consider using only a single variable. The author proposes and estimates a hierarchically organized state interest structure in which specific interests are derived from abstract values. These objectives in turn are assumed to be constrained by core values about a state's vital interests in international society. Applying confirmatory factor analysis (CFA) by LISREL, the empirical results suggest that specific interests can be structured based on three major objectives that describe the general direction the government should take in international affairs: security, economic development, and community interest. These measures provide better theoretical and empirical representations for what we understand about state interests in world politics.
\end{abstract}

Key Words: foreign policy, interests, power, international conflict, structural equation modeling

$\mathrm{W}$ hat are the basic contents and structures of state interests, and where do they come from? The main puzzle in this study is to identify state interests as one example of latent variable issues because they are not directly observable. Scholars of international relations have long disagreed about how to characterize the concept of 'national interest' using appropriate theoretical and empirical methods. It is quite common for scholars to use 'interests' in ambiguous and conflicting ways. This research provides a concrete framework for the structures and contents of state interests, arguing that national interest should

\footnotetext{
*Charles Chong-han Wu(charleswu@uic.edu.hk) is an assistant professor of Government and International Relations at Beijing Normal University-Hong Kong Baptist University United International College. He received his Ph.D. from the University of South Carolina. His research interests include military conflict among democratic and non-democratic countries, especially in East and Northeast Asia. His work has appeared in Asian Survey, Asian Perspective, Maryland Series in Contemporary Asian Studies, American Journal of Chines Studies, and Fudan Journal of the Humanities and Social Sciences. He wishes to thank Harvey Starr, Cameron Thies, John Hsieh, In Tae Yoo, and anonymous reviewers for their comments on this manuscript.
} 
be composed of several general objectives and individual policy indicators. Furthermore, we need to be clear about the causal inferences when providing a detailed conceptualization before undertaking empirical analysis. The goal of this study is to find the causal relationships between different major categories of state objectives and individual policy indicators (the first level of interest components) to determine the linkages between the main concept of interests and other underlying objectives (the second level of interest components).

Most importantly, this study aims to demonstrate how to conceptualize the idea of 'national interest' with more theoretical and empirical correctness. Followed by the theoretical discussions of different categories for each country in the world, I collected data on observed variables and used factor-analytic techniques to confirm that a particular subset of observed variables defined each factor. This paper proposes that applying confirmatory factor analysis (CFA) assists students of relevant studies to create a better model fitting to the true meaning of interests. Furthermore, the adoption of exploratory factor analysis (EFA) helps us to find a model that fits the data. By specifying different individual models, I hope to find a model that fits the data and has theoretical support. These two methodological techniques ultimately can help provide a better understanding of how state interests play a crucial role influencing various forms of political behavior.

\section{DEFINITION OF NATIONAL INTERESTS}

How can we identify state interests? How can we connect state behavior to original intentions? Studying the content of interests might be useful for better understanding the outcomes of state behavior. However, this analytical approach has certain constraints. For instance, when a state is interested in a certain policy, it usually means this option will be chosen from other alternative options when considering all possible constraints. Therefore, it will be risky to judge state interests through their behavior because acting on interests does not mean that states always pursue their first choice, nor does it mean that they will end up with their last choice. States will choose the policy that can bring positive expected utility. One example is the outcome of the war in Vietnam, which does not imply that the United States preferred losing the war to winning it. It was under careful calculation by U.S. President Nixon that the results of accepting defeat were considered better than continuing to pursue victory. Nobody will argue that defeat in Vietnam was Nixon's true preference, but winning his second term by promising peace brought more benefits (Bueno de Mesquita 
2003), so we need to be careful about a conceptualization of interests based only on observable outcomes of policy choices.

Scholars need to think carefully about the origins of national interests in the field of international relations. Frieden informed us that these interests are determined by enduring subnational interests that dominate the formation of national interests (Frieden 1999, 59). Instead of looking at the revealed interests solely from national perspectives, Frieden suggested that we look at interest groups, political parties, and bureaucracies, which interact to form the national interests. State motivations can originate from the interests of bureaucrats or individual actors (Fearon and Laitin 2003); thus, we need to trace national interests to the ideological perspectives of government elites because each individual decision maker has his or her specific role to play with special interests, and these interests will have an impact on final outcomes. The numerous attempts to measure the effect of bureaucratic capacity fall into two broad categories. The first are those using survey measures of bureaucratic quality and expropriation risk (DeRouen and Sobek 2004; Fearon 2005), and the second are those studies estimating administrative capacity indirectly by focusing on the shape of the domestic economy or the state's revenue-generating capabilities (Collier and Hoeffler 2004; Thies 2004; 2005; 2007). It is clear that revealed state interests are the compositions of related actors engaging in political interactions over different economic, political, or social interests.

International relations scholars typically begin with power when studying state interests. In order to identify the interrelationships between interests and power, we need to follow the traditional schools of thought based on the realist approach. Two schools of studies based on the realist approach-the theory that a balance or preponderance of power causes peace-are integral to the equation in their research. In fact, what is perhaps more important is not how the distribution of power causes peace but on how state interests are distributed in the international system. If states are satisfied with the status quo, there will not be military conflict even if they reach power parity with the dominant power. Military conflict exists only when the challenging states have the intention of overthrowing the existing system, and that intention comes from state interests. Without deeper studies of interest similarity, power preponderance only provides partial explanations for military conflict.

A theoretical discussion could offer useful explanations of different indicators of national interests, such as security alliances, trade portfolio, or IGO membership. This paper examines different indicators representing diversified state foreign policy decisions and describes how they perform along the three vital dimensions of security, economic, and community interest concerns. The 
reason for developing and separating state interests into three major areas is due to the complicated nature of interests. Nye (1999) wrote that the definition of interest is a "slippery concept" which may require a more multidimensional analysis rather than an explanation along a single dimension. He argued that state interests are not revealed by the formation of power or security solely, but also include state economic concerns. From the theoretical discussions above, we can see that countries do not only have security or political interests but they also pay attention to economic processes and relations, which may bring strong interdependence effects upon states. Both neorealists and neoliberals agree that national security and economic welfare are important to states (Ashley 1984; Gilpin 2001), and the primary goals of states are diversified in relative emphasis on their focus on security and economic domains. In addition to these two major domains, the third type of interest concern is called "community interests," which originated from the work of Karl Deutsch (1957). Deutsch and his colleagues believed that institutions and the people's sense of community can reinforce and strengthen each other, and this mutual identification can make their interests become not "just instrumentally relevant but integral to one's own purpose" (Russett and Oneal 2001, 166). ${ }^{1}$ In short, it is easier for states to generate similar interests when they join similar organizations or share identical world views. Recent theoretical works have picked up on this theme and have reminded us to pay attention to this type of interest concern (Wendt 1994; Wendt and Duvall 1989).

Very few authors have paid much attention to why and how state interests are related, although there is a general consensus that interests are interrelated. There seems to be a general agreement that state interests are multidimensional; however, there has been very little discussion about the categories for this framework. Thus, since recent work in this area has been encouraging and has demonstrated the lack of research on the issue of interrelationships, a great deal more needs to be investigated to determine correctly how and why specific policy concerns are linked together. In order to answer this question in more detail, this paper begins in the next section with a basic theoretical framework by demonstrating the types of interest objectives. The next step will be to discuss a variety of linkages between abstract and concrete elements that might be missed in a more shallow analysis.

\footnotetext{
${ }^{1}$ NATO is a typical example of Deutsch's concept of a security community.
} 


\section{THEORETICAL DISCUSSIONS}

There are many central social science concepts that cannot be measured easily, including measures of democracy (Bollen 1990; 1993; Coppedge et al. 2008; Treier and Jackman 2008), foreign policy attitudes (Hurwitz and Peffley 1987), state capacity (Cullen 2010), and national identity issues in the study of political involvement (Huddy and Khatib 2007). The concept of national interest also is elusive and vague, and it is difficult to capture in one word or sentence the whole idea. What we understand thus far is that states have different types of interests, including security and economic welfare interests. Different interests will produce distinct decision outcomes. Thus, it is relevant to carefully focus on the vital interests of states. Vital interests mean that states ensure their survival if the requirements of national security and economic prosperity are fulfilled. ${ }^{2}$ Realists argue that all states have a "core national interest" of assuring their physical and territorial integrity. For instance, Enterline et al. (2008), DeRouen and Sobek (2004), and Walter (2006) discovered that larger militaries were associated with a lower likelihood of the onset war, higher likelihood of termination, and shorter war duration, even though Walter argued that military personnel per capita were not associated with the likelihood that governments would accommodate potential separatist movements (Ibid., 326). Liberals posit that nations do not only care about security but also their economic interests. For instance, Lipson (1984) argues that international cooperation is more likely to be sought after in economic issue areas than in security domains. Discussions between neoliberals and neorealists thus inform us that the priority of state goals is to survive through both the preservation of national security and economic welfare. $^{3}$

Relevant research needs to discover the elements of policy concerns and diagnose the relationship among the latent concepts and manifest indicators that are observable. As argued in the previous section, security and economic concerns should be identified as certain latent factors of state interests based on theoretical works. On the one hand, countries focusing more on security interests will attempt to pursue more alliance coalitions for security reasons,

\footnotetext{
${ }^{2}$ The reason security and economic interests are viewed as vital interests is because states will struggle to secure their political or economic benefits when they foresee danger. Other minor interests that create no immediate harm to a nation's survival are not viewed as vital interests in this project.

${ }^{3}$ Countries will definitely fight for their core interests, including in territorial disputes, attacks by nuclear weapons, or the loss of financial markets. These interests can be referred to as "incompatible interests."
} 
stronger military capabilities for national defense, or even the acquisition of nuclear weapons for deterrence. ${ }^{4}$ On the other hand, countries securing more economic interests may pursue free trade, open markets, and foreign direct investment (FDI) opportunities. Generally speaking, economic interests refer to the elements emphasized by political economists, which arguably play very important roles in maintaining world order. For instance, China has shown an average annual growth rate of about eight to nine percent for almost a quarter of a century since economic reforms in the late 1970s (Naughton 2007, 140). China has achieved huge economic success because it paid more attention to the policy considerations of economic issues. Not only China, but other newly industrialized countries tend to treat economic interests, such as trade and FDI, as their major policy concerns. ${ }^{5}$

Hence, bridging the gap between security concerns and economic welfare offers a better structure for studying state interests and cooperation. Reflections on security and economics as state interests soon yield the conclusion that security and economic interests are complementary. Scholars of international relations have suggested that the inclusion of security is not enough to explain national interests; thus, we need to consider economic dimensions as well. Gilpin (1983), Gowa (1989), and Keohane (2005) all agree that international politics is not influenced by security issues only, but also changes with the ebb and flow of global economic relations. Additionally, previous literature has included detailed discussions about whether peace causes more trade, or vice versa (Barbieri 1996; Barbieri and Levy 1999). Evidence has supported the fact that trade and other neoliberal economic policies led to peace (Bliss and Russett 1998; Dafoe 2011; Oneal and Ray 1997; Oneal and Russet 1997; Oneal and Russet 1999; Polachek 1980; 1997).

The peace-through-capitalism perspective has encouraged scholars to adopt similar research agendas in democratic peace studies to find out the true causal mechanisms behind peace and capitalism (Gartzke 2007; Gartzke and Hewitt 2010; McDonald 2009; 2010; Mousseau 2003; 2012; Weede 1996; 2010).

\footnotetext{
${ }^{4}$ In this study, security alliances mainly focus on military alliances for specific security purposes. Alliances also include defensive and offensive alliances.

${ }^{5}$ The economic domain reflects neoliberals' counterarguments about attention to a state's trade behavior. Trade might be considered a fairly common international interaction, but a few factors make it less than appealing. Two states engaging in trade does not imply that they agree on everything in the foreign policy realm. Nations that trade must overcome the transaction costs associated with commerce, and their domestic situation must accommodate the international financial system, which follows globalization. Trade brings an additional economic aspect to describing state interests in this study.
} 
Gartzke's empirical evidence supported the argument that it was financial markets and monetary integration that altogether created more peace among states (Gartzke 2007; Gartzke and $\mathrm{Li}$ 2003). The reason is that peace generally is the outcome among different types of governments once they have strong economic relations, including free trade and market openness. Increased economic involvement between states leads to a more peaceful international order by increasing the opportunity costs of conflict, which deters nations with different regime types from military expansion (Mousseau 2003; Souva and Prins 2006). State leaders will seek to prioritize a stable and safe environment for all global participants to create a more stable environment for investment. These ideas offer a critical and useful theoretical background to integrating the relevant capitalism elements when studying national interest.

In addition to the security and economic domains, there is the third type of major policy concern that links to the core values of state interests. ${ }^{6}$ It includes a normative idea about how states in the international system construct a community of common interests. As Deutsch (1957) showed, it was important to build a shared sense of values and identity among countries because states having similar ideologies or institutions will develop similar policy interests.? This type of concern has strong explanatory power for how states make their foreign policy decisions. One example provided by Russett and Oneal (2001) showed that when people in the European Union (EU) were asked whether they saw themselves mainly as citizens of the EU, about 50 percent did, and this trend was expected to create more benefits for future European integration.

Based on the arguments above, the third type of interest can be viewed as 'community concerns,' which is similar to Deutsch's security community (Starr 1992). Deutsch's model primarily indicates how people obtain mutual benefits through a series of interactions based on an inter-societal transaction regime. Decision makers learn how to separate themselves from other types of states with their overwhelming information (Bueno de Mesquita 1992; Starr 1992). For example, democracies can learn from each other that none of them in the same

\footnotetext{
${ }^{6}$ Regime theorists believe the patterns of international relations cannot be completely explained by the distribution of political and economic power. There should be alternative mechanisms explaining the cooperative behavior of states. According to regime theorists, advanced industrial countries will attempt to "compensate for the increasing fragmentation of power among them by building communication-facilitating institutions that are rich in information" (Keohane 1982). With the erosion of American hegemony in the 1970s, the incentives and necessity for building more international regimes caught the eyes of decision makers and scholars. This was the function offered by the high institutionalization of postwar regimes that prevented the lack of cooperation.

${ }^{7}$ Deutsch and his colleagues suggested that "institutions and people's sense of community can reinforce and strengthen each other" (Russett and Oneal 2001, 166).
} 
community prefers using force or going to war as a method of conflict resolution. A "dove-like nature" thus will bring more peace among member states and make the community more integrated. The characteristics of "feeling" and "trust" derived from similar institutions will encourage states to look for more chances to cooperate. States in the same security community tend to have similar policy objectives, which tie all member states together. In this paper, it is proposed that when states make an effort to demonstrate these inherent objectives, they are more likely to generate certain types of policy choices, such as maintaining similar political ideologies (democratic or autocratic regimes), having close living standards, or gaining membership to similar IGOs (Boehmer et al. 2004; Mitchell and Hensel 2007; Anderson et al. 2016). Under this definition, states attempt to construct a concert of similar identities and compliance where units can expand interactions and eventually achieve strong interdependence.

The three major types of interest revelations are arrayed in Figure 1 according to the theoretical arguments. States encounter distinctive global issues, and state leaders need to adopt relevant policies to handle those issues. For instance, does the government adopt a more security-oriented policy, or does the government place greater emphasis on economic policy? The policy categories displayed in Figure 1 are the basic themes studied and defined by international relations scholars. To use a simple example to illustrate the classification, we need to ask whether an individual state increasing its military spending depends on whether the state prefers to address its security or economic objectives/ concerns. If the state prefers focusing more on security affairs, it probably will struggle to increase national capabilities or build up more defensive alliances. Hence, I expect these concepts to conform to the latent framework model, where more abstract elements constrain more specific issues. At the most concrete level, the variables in the right column are indicators for specific policy values. They are alliance numbers, national capabilities, nuclear weapons possession, intergovernmental organization membership, international trade, regime type, economic development, financial openness, and total foreign direct investment. These diversified elements are constrained by the second tier of abstract objectives concerning the type of specific interests that go into decisionmaking. These categories are normally referenced to see which types of interests governments have.

What are the major values that contain these three categories of concerns? The first tier of the path diagram in Figure 1 displays what we believe to be the idea of state interests. The vital values can be viewed as the principal components that organize and compose governmental actions or decision-making. They have strong links to individual policy concerns. For instance, states surrounded 
Figure 1. The Confirmatory Factor Model of National Interest

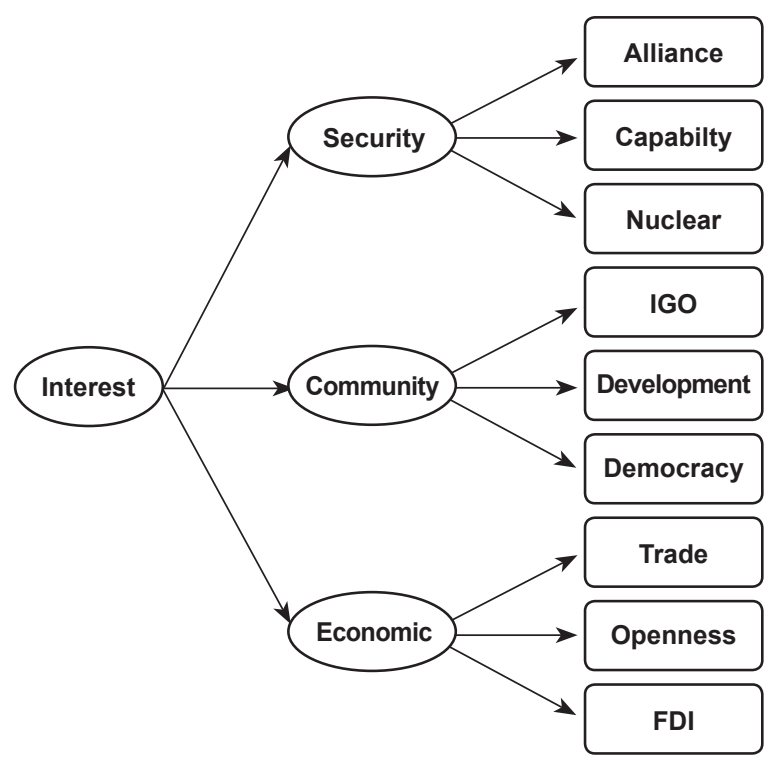

by strong rivals are more likely to see an increase in their desire for national security, which will increase their willingness to strengthen their national defense capabilities or even develop nuclear weapons. It is also true that placing a higher value on achieving economic goals will result in more opportunities for international trade or market openness. Then, if the theoretical arguments are correct, what has been left is an overall picture analyzing what the structure of national policy interests looks like and the paths leading from the core cognition values to each concern with relevant manifest variables constructing these objectives.

The fundamental values and particular state interests will be described in greater detail below. The aim here is to construct an innovative framework combining factor-analytic studies with the discussion about the direct relationship between general and specific elements in a belief system. This study also contributes to the idea that using a multidimensional model can give us a different, and better, measurement of state interests. 


\section{MODEL SPECIFICATION}

When applying factor analysis, there are usually two types of methodologies adopted by researchers. The first type is exploratory factor analysis (EFA). This methodology is mostly used on collected variables that do not have any existed factors fitting the observed data. ${ }^{8}$ The second is confirmatory factor analysis (CFA). In CFA, researchers attempt to test the hypothetical factor model with statistically significant results, which means using the existing variables to confirm the model. One of the advantages of CFA is to show methodological refinement by revising the measurement error. In regular regression or other path analysis, observed variables are not always perfect for measuring all phenomena, so sometimes researchers just assume those observed factors are perfectly valid and reliable. Many scholars do not correct the measurement error issue, which will easily cause problems for biased parameter estimates (Kim and Mueller 1978a; 1978b; Schumacker and Lomax 2004). Thus, adopting CFA can help researchers to generalize some latent variables, which will take into account the measurement error.

The functions are different between CFA and EFA. In EFA, we mainly ask how many underlying dimensions there are for the given data so that we can quickly ascertain the minimum number of hypothetical factors that can account for the data. In short, EFA is used for data reduction and dimensional exploration. It is also applicable to the generation of one latent variable representing the whole concept of the abstract variable. For example, EFA can help us generate the overall value for the ideas of interests from the collected policy variables.

However, in order to have a more comprehensive explanation and investigate the theoretical dimensions of policy interests, it is important to consider a more heuristic device that can examine the hypothetical factors with directed path structure. Based on previous theories, we can assume that there are three focal dimensions for state policy concerns, including security, economics, and community. CFA can help us to see if there are any model misspecifications in the hypothetical model. For instance, some issues might be related to whether we should put state development into community or economic concerns. Here, CFA may be used as a means of identifying the more appropriate model by comparing the model fit indices. The statistical outcomes offer a strong indicator of whether we should put development into community or economic concerns

${ }^{8}$ Scholars have explored which observed variables defined each construct or factor (Kim and Mueller 1978b). In EFA, researchers have explored how many factors there were and which observed variable explained the factors more than others. 
for this project. In general, CFA offers us a better understanding of the real meaning and dimensions of key variables.

The model applied here cannot be estimated by traditional factor analysis procedures. Based on recommendations from previous research, running a LISREL model was chosen (Jöreskog \& Sörbom 2001). Jöreskog \& Sörbom LISREL 8.8 offers the analysis of covariance structures to help estimate policy interests. The model I assume is that more concrete policy interests are determined by more abstract concerns at higher levels. First-order CFA provides identifications for the relationships between abstract concerns and specific policy behaviors. For example, security concerns have more influence on alliance formation and maintenance, national capabilities, and nuclear weapons acquisition and development. Economic concerns will lead to more activities on trade, foreign direct investment, and market openness. Community concerns will help states to think more about their general quality of life compared to other states, which will be imperceptibly influenced by their policy preferences on revising their regime types, joining certain international organizations, or elevating domestic living standards. The first level of CFA thus introduces a clear picture identifying diversified state behavior with clustered national objectives.

The second level of order reveals that each concern is assumed to be determined by the core value of interests. Since it is extremely difficult to list out all concerns for every state, this approach offers an efficient and parsimonious framework. I argue that state concerns can be categorized by three main groups, and each has a direct link to the core value of interests, and this structure composes the second order of the CFA model. In short, a hierarchical ordering shows that a more abstract idea can be explained by a slightly clearer concept of the next order (Figure 1).

\section{DATA}

There are various ways in which states express their interests. States can reveal their security interests through either costly or information-rich signals, where the signals are basically state behavior. Previous research has shown how to represent state security interests through the discussions of alliance composition (Bueno de Mesquita 1983; Gibler and Sarkees 2004; Leeds et al. 2002; Maoz 2000), militarized conflict (Fearon 1995), and United Nations voting (Gartzke 1998; Voeten and Merdzanovic 2009). However, vital interests should not be limited only to the study of security concerns. Instead, we should attempt to include more diversified behaviors, which should lead to relative typologies that 
we can then synthesize as components of interests.

Table 1. Sources for Policy Indicators

\begin{tabular}{c|c}
\hline Variables & Source \\
\hline Alliances & Taub by EUGene \\
National Capabilities & COW v2.3 \\
Nuclear Weapons & Jo\& Gartzke (2007) \\
IGOs & COW v2.3 \\
Development & Mousseau (2000) \\
Democracy & Polity IV \\
International Trade & Gleditsch (2002) \\
Market Openness & IMF \\
FDI & IMF \\
\hline
\end{tabular}

To estimate the structural equation modeling it is necessary to measure state interests not only from specific items but also from the first order of abstract concerns and the second order of core values. I collected data for countries around the world from 1966 to 1992. The specific variables are listed in Table 1. Based on past theoretical work, three indicators were constructed for security concerns: alliance portfolio (X1), national capabilities (X2), and nuclear weapons possession $\left(\mathrm{X}_{3}\right){ }^{9}$ The dimension of security concerns would be clearly illustrated if these three indicators could be included as parts of the critical variables. States put more emphasis on increasing national capabilities (Wright 1964; Waltz 1979), sustaining similar alliance formations (Bueno de Mesquita 1983), or even developing (or acquiring) nuclear weapons to make up their chief security concerns if there are any security issues in their surrounding area (Jo and Gartzke 2007; Gartzke and Kroenig 2009).

Intergovernmental organization (IGO) membership (X4), domestic development (X5), and regime type (X6) are the measurement components of community interests. ${ }^{10}$ Souva $(2004,256)$ argued that states with similar institutions

${ }^{9}$ Alliance portfolio is designed to measure the similarity of alliance formation for different countries in the world. National capabilities are in index scores. CINC scores (COW capabilities index) are used for the indicator of national capabilities, which ranges from o to 1. Nuclear weapons possession are dummy variables which demonstrate 1 if the state possesses nuclear weapons and $o$ otherwise.

${ }^{10}$ I divide IGO memberships by 10 , which makes the data range from 0 to 10 . Higher values mean states have joined more intergovernmental organizations. Economic development is mea- 
experienced fewer ideological disagreements because "ideologies and institutions [were] in a co-evolutionary process." Thus, it can be hypothesized that states with similar domestic qualities (situations) will be more likely to form common concerns, such as the United States and other anti-communist countries during the Cold War era. Countries in the democracy bloc have similar objectives, and those can be used as the means to achieve particular behaviors or outcomes. In brief, countries with close identities will try to establish more democratic and developed societies, or what could be called "dove-like" communities.

The last three variables of the model are trade ( $\left.\mathrm{X}_{7}\right)$, market openness (X8), and FDI (X9), which are used to represent economic concerns. ${ }^{11}$ Each variable was checked to verify whether it had the same standard deviation and mean. All variables were available from 1966 to $1992(\mathrm{~N}=2926) .{ }^{12}$ However, because the techniques testing cross-sectional time-series data are underdeveloped in latent variable models, I had to examine the specific choices and concerns during different periods of time (1970, 1980, and 1990) for all countries. The reason I investigated the latent factors in three different years was because it might have offered a few insights into diversified preferences. For instance, countries might have tried to focus more on economic than security issues in 1990, especially as economic interdependence became increasingly popular among countries. This research is attempting to discovery whether there was any identifiable diversity in these three years. The second order of CFA needs more articulation to show the theoretical directions between the latent interest concerns and manifest indicators. The selection of these concerns has been motivated by previous debates about basic principles of state survival. The idea mainly comes from discussions among different schools of thought in international relations, including attention to the topics of security, economic development, and community issues. In addition, this typology was also influenced by work promoted by Kegley and Wittkopf (1982) and Hurwitz and Peffley (1987). The former have clearly identified and detailed a typology of interests, while the latter have offered an advanced methodological review. These works provide

sured by GDP per capita. Polity III data was adopted to determine regime type, such as democracy. It is a dummy variable with democratic regimes coded as 1 .

${ }^{11}$ I adopted the IMF's market openness index evaluated in previous studies (Gartzke 2007), which makes the difference between eight and the sum of eight types of government market restrictions. The higher scores of this index mean more market freedom.

${ }^{12}$ When conducting CFA, the technique requires more organized data for the completion of models. Data used from 1966 to 1992 had fewer problems with missing data, helping to provide the available empirical results. The $\mathrm{N}=2,926$ means that it covers nine different policy variables for all countries between 1966 and 1992, and this country-year dataset gives us 2,926 data points in total. 
great guidelines for future students in international politics to study how to analyze an abstract topic with concrete and available datasets.

\section{RESULTS AND ANALYSIS}

The estimated parameters among the indicators and the latent ideas of interest concerns are presented in Table 2. In general, the results appear to be fairly close to the theoretical arguments. The general idea of interests is sufficiently explained by the three major concerns of security, community, and economics with statistical significance for the years 1970, 1980, and 1990, respectively. The initial model (M1) from Table 2 was estimated using the 1970 data and CFA with the maximum likelihood estimation. The use of maximum likelihood estimation (in LISREL-SIMPRIS) for measuring first-order factors is only accurate on interval or ratio variables. Due to the issue of multivariate non-normality created by the two dichotomous variables in the dataset (nuclear weapons and democracy), the study followed the suggestion by Schumacker and Lomax (2010) to include the use of tetrachoric, polyserial, and polychoric correlations to adjust the matrix in the maximum likelihood estimations. The method of handling nonnormal data in LISREL is to use an asymptotic covariance matrix as input with a polychoric correlation matrix (Ibid., 62). ${ }^{13}$ On the second order of CFA, we find that economic concerns offer stronger effects on vital interests than the other two categories $(\beta=1.40)$. Security and community concerns are both significant with lower estimated coefficients (.52 and .72). The size and significance of the relationships between the core values and concerns provides an interesting insight for the study of interest objectives during the Cold War era. The results suggest that states pay more attention to economic-related policies than security or identity issues.

A closer inspection of the connections among concerns and specific items turns up a number of interesting findings. The three concerns were crucial considerations for helping states to decide a variety of concrete issues in 1970 . The effect of security concerns in M.1 corresponds to my expectations: states that have more security concerns will tend to seek stronger national capabilities ( $\beta=.02)$ in general, or they will attempt to seek for more security alliances $(\beta=.23)$. Though the effects are not particularly large for these two interest choices, it is still apparent that security concerns play a significant role in increasing a country's general power, as well as significance of acquiring nuclear arms in 1970.

${ }^{13}$ The numbers of the factor loadings in Table 2 are standardized factor loading coefficients. 
Table 2. CFA Model

\begin{tabular}{|c|c|c|c|c|}
\hline & M.1 (1970) & M.2 (1980) & M.3 (1990) & M.4 (Revised) \\
\hline \multicolumn{5}{|c|}{ 1st Order CFA } \\
\hline Alliance & $\begin{array}{c}0.23 \\
(0.95)\end{array}$ & $\begin{array}{c}0.39 \\
(0.85)\end{array}$ & $\begin{array}{c}0.57 \\
(0.67)\end{array}$ & $\begin{array}{c}0.25 \\
(0.94)\end{array}$ \\
\hline Capabilities & $\begin{array}{l}0.02 \\
(.00)\end{array}$ & $\begin{array}{c}0.65 \\
(0.57)\end{array}$ & $\begin{array}{c}1.04 \\
(0.09)\end{array}$ & $\begin{array}{c}0.18 \\
(0.97)\end{array}$ \\
\hline Nuclear Weapons & $\begin{array}{c}0.93 \\
(0.13)\end{array}$ & $\begin{array}{c}0.84 \\
(0.30)\end{array}$ & $\begin{array}{c}0.63 \\
(0.60)\end{array}$ & $\begin{array}{c}2.38 \\
(0.46)\end{array}$ \\
\hline IGOs & $\begin{array}{c}0.56 \\
(0.69)\end{array}$ & $\begin{array}{c}0.71 \\
(0.49)\end{array}$ & $\begin{array}{c}0.60 \\
(0.63)\end{array}$ & $\begin{array}{c}0.52 \\
(0.73)\end{array}$ \\
\hline Development & $\begin{array}{c}0.70 \\
(0.51)\end{array}$ & $\begin{array}{c}0.39 \\
(0.85)\end{array}$ & $\begin{array}{c}0.87 \\
(0.24)\end{array}$ & $\begin{array}{c}0.91 \\
(0.17)\end{array}$ \\
\hline Democracy & $\begin{array}{c}0.78 \\
(0.40)\end{array}$ & $\begin{array}{c}0.40 \\
(0.84)\end{array}$ & $\begin{array}{c}0.44 \\
(0.81)\end{array}$ & $\begin{array}{c}0.54 \\
(0.71)\end{array}$ \\
\hline Trade & $\begin{array}{c}0.47 \\
(0.78)\end{array}$ & $\begin{array}{c}1.00 \\
(1.07)\end{array}$ & $\begin{array}{c}0.76 \\
(0.42)\end{array}$ & $\begin{array}{c}0.72 \\
(0.48)\end{array}$ \\
\hline Market Openness & $\begin{array}{c}0.78 \\
(0.40)\end{array}$ & $\begin{array}{l}-0.04 \\
(1.01)\end{array}$ & $\begin{array}{c}0.21 \\
(0.95)\end{array}$ & $\begin{array}{c}0.18 \\
(0.97)\end{array}$ \\
\hline FDI & $\begin{array}{l}-0.00 \\
(1.00) \\
\end{array}$ & $\begin{array}{l}-0.77 \\
(1.04) \\
\end{array}$ & $\begin{array}{c}0.08 \\
(0.99) \\
\end{array}$ & $\begin{array}{c}0.20 \\
(0.96)\end{array}$ \\
\hline \multicolumn{5}{|c|}{ 2nd Order CFA } \\
\hline Security & 0.52 & 0.98 & 0.42 & 0.16 \\
\hline Community & 0.72 & 0.75 & 0.63 & 1.54 \\
\hline Economics & 1.40 & 0.72 & 1.63 & 0.68 \\
\hline $\mathbf{N}$ & 135 & 156 & 165 & 165 \\
\hline
\end{tabular}

Furthermore, democracy and national development account for a significant part of community concerns. There are very clear effects from national development $(\beta=.70)$ and democracy $(\beta=.78)$ on community concerns. My findings suggest that states with similar social and domestic conditions tend to have similar interests. The third aspect of national interest, economic concerns, represents a significant predictor for trade, FDI, and market openness. States favoring economic-oriented policies are more likely to open their markets to foreign investors $(\beta=.78)$. My findings show that market openness is significant in 1970, which supports what Gartzke has proposed: financial and monetary openness are possibly most relevant as mechanisms for revealing information. Countries will prevent any harm or potential risks of losing valuable opportunities if they have strong incentives for economic integration (Gartzke 2007). However, the other indicator of economic concerns, foreign 
direct investment, has a negative impact $(\beta=-0.00)$, which tells us that foreign direct investment was not a popular choice among policymakers in $1970 .{ }^{14}$ States preferring less net inflows of foreign investment might come out with strong state protections for local business.

I also compared the estimated parameters for specific issues in 1980 and 1990 (Table 2). M.2 gives us similar results as M.1. Countries in 1980 have shown similar interests. Market openness and FDI both have negatively significant effects on state economic concerns in 1980. It is apparent that states in 1980 measured market openness and FDI categorically different from trade, and preferred a more closed economic policy rather than actively encouraging foreign investors and companies to relocate their capital. I then ran the third model (M.3) and examined the empirical outputs. Market openness contributed to economic concerns with positively significant results $(\beta=.21)$, and the effects of FDI also became significantly positive $(\beta=.08)$. The second order CFA provided further supporting evidence for the arguments above. Security lost slight influence on the composition of interests but still remained positively significant (.42) in 1990. Economic concerns demonstrated strong and significant effects on the major idea of interests. In general, my findings corresponded to what scholars have observed thus far about the current trends of globalization and financial integration. The three concerns are accounted for quite well by the idea of a general vital interest for each nation-state, which gives an alternative measurement for this abstract concept in international politics.

An important step of the estimation process in analyzing the confirmatory factor models is to fit the sample variance-covariance data to the specified model. If the model fits the data, then we can confirm the specified model is supported by the sample data. If the model is not supported, then we must modify the model to achieve a better fit. In this section, I illustrate all model-fit indices for the three examined models in the previous section. The results are summarized in Table 3.

The first model-fit index is to ensure the chi-square $\left(\chi_{2}\right)$ fit into the model. The null hypothesis of the chi-square $\left(\chi_{2}\right)$ test shows that the model structure perfectly predicted the variances and covariances of observed data (Bollen 1993; Hu and Bentler 1998; Schumacker and Lomax 2004). In short, the ideal situation is when observed and implied variance-covariance matrices are identical, and the chi-square $\left(\chi^{2}\right)$ test should be non-significant. ${ }^{15}$ The $\chi^{2}$

\footnotetext{
${ }^{14}$ The negative factor loading of FDI in 1970 may have resulted from the quality of the data, and so deserves further study of better data options.

${ }^{15}$ A better model fit means a non-significant $\chi 2$ test. However, the $\chi^{2}$ model-fit criterion is sen-
} 
Table 3. Model Fit Indices

\begin{tabular}{lcccc}
\hline & M.1 (1970) & M.2 (1980) & M.3 (1990) & M.4 (Revised Path) \\
\hline RMSEA & 0.17 & 0.18 & 0.09 & 0.09 \\
NNFI & 0.12 & 0.52 & 0.84 & 0.36 \\
CFI & 0.42 & 0.72 & 0.89 & 0.63 \\
SRMR & 0.15 & 0.11 & 0.10 & 0.14 \\
GFI & 0.78 & 0.84 & 0.90 & 0.82 \\
AGFI & 0.58 & 0.65 & 0.82 & 0.61 \\
\hline Df & 24 & 21 & 24 & 21 \\
Chi-square & 98.76 & 136.31 & 55.55 & 164.63 \\
p-value & 0.00 & 0.00 & 0.00 & 0.00 \\
\hline
\end{tabular}

degrees-of-fit in M.1 is 98.76, with 24 degrees-of-freedom and p-value<.05, which indicates that the observed and implied variance-covariance matrices are identical. This result does not give us the evidence of goodness-of-fit due to the insufficient sample size. Thus, I also list other available model-fit indices to identify whether M.1 fits the data well, including RMSEA, NNFI, CFI, SRMR, GFI, and AGFI. For this model, RMSEA (.17) shows it has an average model-fit. Standardized root mean square residual (SRMR) also offers moderate model-fit results (.15). Other indices, such as AGFI (.58) and CFI (.78) offer fitting values for the data. In general, all the measures for M.1 have average model fit. ${ }^{16}$ For M.2, the $\chi^{2}$ statistic is equal to 136.31 with 21 degrees of freedom, and $\mathrm{p}<.05$. The $\chi^{2}$ statistic is still significant. Other indices, RMSEA (.18), SRMR (.11), AGFI (.65), NNFI (.52), and CFI (.72), all reveal a goodness-of-fit model. M.3 has better model-fit indices than M1 and M2. Even the $\chi^{2}$ test was unexpected $(\mathrm{p}<.05)$, and other indicators demonstrated better results than M1 and M2. RMSEA and SRMR locate in a moderate range (.09). In addition, although AGFI (.82) and NNFI (.84) have slightly lower values, CFI and GFI are still in a good range.

sitive to the sample size (the lager the sample size is, the easier it is to get a significant result). Therefore, scholars sometimes just discount the meaning of a $\chi^{2}$ indicator (Bentler 1990; Hu and Bentler 1998; Schumacker and Lomax 2004; Heene et al. 2001).

${ }^{16}$ The model-fit indices in Model 1 offer some moderate results, which may not strongly support the proposed structure of national interest in this study. However, as the indices of Model 2 and 3 improve the results for model-fit, we still can obtain inspiration about the potential structure and contents discussed in this paper. More data collection may be needed to improve methods for empirical examination in the future. 
Modification indices in the LISREL output offer suggestions on how to further improve the model-to-data fit. In order to obtain a better model fitting the data, I tried adding a new path from the latent concerns to the observed interest variables for countries in 1990. Adding a new path to observed variables should include theoretical explanations. For instance, I switched the path and created model 4 since it was reasonable to doubt that state development should be under the considerations of economic concerns. The modified theoretical model with relevant information is listed in Table 2 (model-fit index in Table 3). The LISREL output indicates that adding state development to economic concerns make no significant difference between M.3 and M.4. In addition, if we compare the model-fit indices, M.4 has no better fitted value to the data than M.3. The minimum $\chi_{2}$ fit function remains significant $\left(\chi_{2}=164.63, \mathrm{df}=21\right.$, and $\mathrm{p}<.05)$. Other model-fit indices are all worse than the M.3 data, which offers a worse framework than what I had created for the original structural equation model. The findings inform us that we can consider development with other liberal variables in the same cluster, such as democracy and IGO membership, which offers a better explanatory framework, which is what Russett and Oneal had argued in their work on triangular peace (2001). In fact, democracies are more likely to stay with countries with similar development standards and IGO preferences, giving them the ability to organize societies with similar ideas of "ingroup" consensus (Hermann and Kegley 1995).

The detailed map of state interests offers a clear illustration for the structure of interests. In general, interests can be explained by three different categories of objectives: security, community, and economic aspects, if the CFA above is correctly specified and examined. ${ }^{17}$ Each objective in turn contains critical determinants of interests across a wide range of choices. The alternative methodology to investigate the theoretical structure of state interests that I adopted above is correctly specified. The EFA could help researchers explore how many factors there are, whether the factors are correlated, and which observed variables appear to be the best measures of each factor. Generally speaking, EFA offers strong empirical evidence supporting the theoretical structure established by the CFA.

Based on the map of the structures of interests, states have three different

\footnotetext{
${ }^{17}$ This empirical study is also derived from several theoretical articulations about the system of policy studies. Gilpin (1983) clearly points out that politics is not influenced by security or political issues alone, but also by economic factors. In addition, Deutsch (1957) mentioned that a shared sense of values and identity among countries should be counted as another type of interest because this type of concern has strong explanatory power for how states make decisions. My structural equation model offers useful empirical evidence, with the model-fit values supporting the argument.
} 
types of objectives, which contain individual interest choices. First, if countries attempt to maintain close national capabilities, to acquire similar amounts of nuclear weapons, or to achieve identical alliance portfolios, there is a higher probability that these countries share close security ideas about world politics. Realists believe that security is mainly measured by military capabilities, and states focus on their survival by increasing those military capabilities. Thus, my first hypothesis in EFA is that countries possessing greater levels of security similarity can be identified with higher levels of general interest similarity.

Political scientists also have argued that countries with similar political or domestic institutions attempt to form close decisions (Souva 2004), and this similarity will bring fewer ideological disagreements and help to create an ideal community of interests (Denzau and North 1994). If countries have identical domestic conditions, such as similar scores on democratic and development scales, it is more likely for the leaders to generate cognate decisions. My second factorial hypothesis, therefore, argued that countries with greater levels of community interests will possess higher levels of general interest similarity.

Finally, countries that have analogous economic policies may show some affinity in their interests generally. Economic interests have eclipsed security interests on the scale of strategic importance to states. National power in this context is measured by the aggregate of a number of components such as exportable capital, percentage share of the global economy, foreign direct investment, and the will to mobilize one's economic capabilities to achieve national goals. Thus, it is important to identify if countries share their economic interests with each other in order to accelerate a more integrated program of economic cooperation across the world. My last hypothesis examining the latent framework of interests stressed that countries with a greater similarity of economic interests will possess higher levels of affiliation.

By using country-year data to examine all three hypotheses above, I intended to show that the structure of overall interest similarity is composed of three major interest objectives. I argued that a combination of factors contributed to state interests by employing the principal factor analysis to reduce the nine variables in the theoretical model to a single interest variable indicator. There are three major interest factors (security, community, and economics) shown as objectives that have direct paths to individual variables. EFA mainly explored the collected data, and presumed that some factors that have smaller numbers than the observed variables were responsible for the shared variance-covariance among the observed variables (Everitt 2005). 
Table 4. Factor Loadings for the National Interest

\begin{tabular}{lccc}
\hline \multirow{2}{*}{ Variables } & \multicolumn{3}{c}{ Three-Factors Model } \\
\cline { 2 - 4 } & Factor 1 & Factor 2 & Factor 3 \\
\hline Alliances & 0.751 & 0.129 & -0.041 \\
National Capabilities & 0.827 & 0.142 & 0.042 \\
Nuclear Weapons & 0.755 & 0.178 & 0.004 \\
IGOs & 0.202 & 0.817 & -0.002 \\
Development & 0.197 & 0.745 & 0.415 \\
Democracy & 0.038 & 0.855 & 0.099 \\
International Trade & 0.454 & 0.027 & 0.009 \\
Market Openness & 0.049 & 0.080 & 0.848 \\
FDI & -0.067 & 0.183 & 0.824 \\
Eigenvalue Proportional Explained & 0.235 & 0.229 & 0.176 \\
Cumulative Proportional Explained & 0.230 & 0.460 & 0.640 \\
\hline
\end{tabular}

Table 4 uses a three-factors model covering the nine different variables with almost 64 percent sample variance. The first hypothesis argues that security interests represent one part of the latent factors of the major component. The first three operational measures in Table 4 load heavily on one communality. The underlying domain explains 75 percent of the variance in the number of alliances, 82 percent of the variance in national capabilities, and also tells us 75 percent of the variance in nuclear weapons capabilities. These results suggest that the concern of security issues in world politics should be included in the study of decision making.

Secondly, community interests suggest that countries with similar domestic and international standards, including similar polity scores, development scales, and activities in international organizations, will shape up to have closer interests to one another. The results of the EFA support my hypothesis with strong factor loadings on the second factor. IGO membership explains 82 percent of the variance, domestic development 75 percent, and democracy 85 percent. This probably tells us that states that have similar democratic and living standards are more likely to form similar foreign policies and construct a more similar community of mutual interests.

The third hypothesis received strong empirical support showing that the general idea of interests is strongly related to economic affairs. The third factor loading, which consists of international trade, market openness, and 
FDI, contains the variance of $.01, .85$, and .82 , respectively. The factor loading of international trade reminds us of one critical point. It demonstrates a comparatively small loading for the third factor; however, this variable loads minimally or disproportionally for the first two factors. This probably indicates that these three components of economic activities fit into the third interest factor very well. Factor analysis encompasses both correlation and covariance matrices to show the relationships among the observed variables. It offers a convenient method for identifying the relevant indicators to explain the latent framework.

The empirical analysis has brought us some theoretical inspirations throughout the study. In fact, it has a basic outline for recognizing a country's specific policy focus by the inclusion of the methodology with contributions to realism's unsolved puzzles. Realists have taught us that, in order to maintain the basic requirement of survival for each state, leaders need to secure more "power" as a vital interest for their nation-states. Hence, scholars are mainly defining power as the critical component of a state's vital interests; however, this definition has narrowed our understanding about the contents and dynamics of national interest. A state's interests should have broader dimensions with various policy factors, and so an innovative methodology examining the hypotheses of the linkages between general objectives and policy factors has become necessary.

The empirical findings in this study show that states paid more attention to security interests in 1980 than in 1970 or 1990 by seeking stronger national capabilities in general during the Cold War. This political phenomenon is based on the military competition and arms race between the United States and the Soviet Union in the 1980 s when both powers were struggling through the security dilemma assumed by the realists. For instance, the Strategic Defensive Initiative (SDI), including different formats of missile defense systems and the development of Intercontinental Ballistic Missiles (ICBM) initiated by Ronald Reagan, had raised the attention of other major powers in the world. Most of the major powers switched their focus to strengthening the development of their militaries and missile technologies, and attempted to secure their survival by achieving military supremacy.

Economic interests have always been a critical factor when studying state interests. Because several mechanisms associated with capitalism are capable of mitigating the causes of war, states with similar policy preferences, especially economic incentives, have no need to fight because little can be gained from victory (Gartzke 2007, 171). As Gartzke proposed, financial and monetary openness were arguably most relevant as mechanisms for revealing state interests and information. Based on my statistical findings, market openness and 
FDI both had negatively significant effects on state economic concerns in 1980. It is apparent that, in 1980 market openness and FDI probably measured different concepts and constructs than trade measured. This may tell us that states preferred a less open economic policy and did not welcome foreign investors and companies to relocate their capital. However, as globalization flourished in 1990, more and more countries opened their domestic markets to attract more foreign investors. For example, not only China, but India, Vietnam, and other countries in Southeast Asia also welcomed more foreign direct investment.

Finally, the statistical results also suggest that community interests should be included in considerations of major state preferences. Political institutions and the people's sense of community can reinforce and strengthen each other, and states with similar ideologies will establish close societies with shared interests. For instance, leaders from democratic countries know how to separate from other countries with different regime types; while those democratic leaders prefer using less conflict-prone methods to bring more peace among communities. A "dove-like nature" brings community members together and builds up a sense of "ingroup" with similar feelings and trust. These types of interests will also expand the opportunities for cooperation within democratic groups. Based on the arguments and empirical examinations in this study, in addition to the security and economic domains, community interest represents the third policy concern that links to the core values of national interest. These results correspond with those of one of the most well-studied IR theories-the democratic peace theory.

\section{CONCLUSION}

This study provides the first latent framework and evidence that CFA is present in widely discussed issues of national interest. In contrast to previous conceptualizations and usages of interests, I detailed a method of operationalization that made the concept of national or state interests more comprehensive. Only through an overall discussion about the true dimensions of interests can we understand the complete contents. Focusing on a single indicator might give us only a partial vision of state interests. Determining which elements of interests spoke more directly to theory, and then to choose among the various index alternatives based on which elements have been operationalized, was challenging. The introduction of the methodology helps us solve for the complexity by mapping out the structures of this multifaceted concept. 
From the empirical results, it was determined that the core values of national interest can be explained by three different types of concerns: security, community, and economic. These concerns in turn are important determinants of specific interests across a wide range of choices, such as the development/ expansion of national capabilities, nuclear weapons possession, regime type, national economic development, market openness, and foreign direct investment. This means that there might be a hierarchical structure within the belief systems of all countries when making decisions on foreign policies. This project attempted to show what that structure looked like, and then provided a useful framework for further studies on the effects created by those interests.

Since this study attempts to examine some hypothetical paths among latent and manifest variables for different state interests, critics might argue that it is difficult to list and organize all possible items with correct paths to their higher order of concerns. Gartzke (2000, 195-196) responded to those critics by saying, "The problem again is that we cannot observe preferences; we must rely on assumptions or some indirect representation. The trick, then, is to construct an indicator that is likely to be minimally affected by sources of bias, but we can evaluate the degree to which actors coincide or diverge in their expressions of representative behavior." It is true that we cannot explain all state behavior by all state interests simultaneously using the most parsimonious of models. The best way to reveal the idea of interests is to construct an index with less measurement error and based on relevant theories. All models cannot exist without clear and strong theoretical support. Thus, the model and methodology offered in this study sufficiently fulfill the requirements for such an abstract idea. We can see how states attempt to cope with extraordinarily complex choices by structuring views about specific choices according to their broader and more abstract beliefs.

Another advantage of this study was to make comparisons among different choices. It helps us to identify how, and under which conditions, states will focus on specific behaviors. For instance, some choices are better understood than others, such as developing capabilities, acquiring nuclear weapons, or opening markets. Our speculation has revealed that the reason why some interests were salient was because of each country's focus on special concerns and promotion of those specified choices. Political leaders who paid more attention to securityrelated issues were more likely to at least fulfill their country's basic needs on security capabilities or nuclear arms acquisition. This orientation probably would still be obscured if we only had investigated one indicator. However, as more items were added into the latent framework, we were able to categorize each interest group and have a much clearer picture for each dimension.

Finally, there were limitations to this current study that need mention. First, 
the significance levels for each of the interest variables and their paths to the first order were still moderate. In order to have better empirical results in this case, more work finding other sources of data was needed. Second, after investigating the major contents of state interests and understanding the basic cognitive frameworks of policy orientations, we can move to the next steps: constructing a dyadic index made up of multiple interest choices and then study the connections to interstate conflicts. Examining the true validity of this critical independent variable and ensuring it has enough variation for statistical estimation thus become more critical. Lastly, an alternative explanation of the structures and contents of national interests may be required in the future, and more discussions about the concept may be necessary before we can generate a better artificial indicator for national interest.

\section{REFERENCES}

Ashley, Richard K. 1984. “The Poverty of Neorealism.” International Organization 38(2), 225-286.

Barbieri, Katherine. 1996. "Economic Interdependence: A Path to Peace or Source of Interstate Conflict?” Journal of Peace Research 33(1), 29-49.

Barbieri, Katherine and Jack S. Levy. 1999. "Sleeping with the Enemy: The Impact of War on Trade." Journal of Peace Research 36(4), 463-479.

Bentler, Peter M. 1990. "Comparative Fit Indexes in Structural Models." Psychological Bulletin 107(2), 238-246.

Bliss, Harry and Bruce Russett. 1998. "Democratic Trading Partners: The Liberal Connection, 1962-1989." Journal of Politics 60(4), 1126-1147.

Bollen, Kenneth A. 1990. "Political Democracy: Conceptual and Measurement Traps." Studies in Comparative International Development 25(1), 7-24. 1993. "Liberal Democracy: Validity and Method Factors in CrossNational Measures." American Journal of Political Science 37(3), 12071230.

Boehmer, Charles, Erik Gartzke and Timothy Nordstrom. 2004. "Do Organizations Promote Peace?” World Politics 57(1), 1-38.

Bueno de Mesquita, Bruce B. 1983. The War Trap. New Haven: Yale University Press.

Bueno de Mesquita, Bruce B. and David D. Lalman. 1992. War and Reason: Domestic and International Imperatives. New Haven: Yale University Press.

Christopher, Anderson C., Sara McLaughlin Mitchell and Emily U. Schilling. 
2016. "Kantian Dynamics Revisited: Time Varying Analyses of Dyadic IGO-Conflict Relationships.” International Interactions 42(4), 644-676. Collier, Paul and Anke Hoeffler. 2002. "On the Incidence of Civil War in Africa.” Journal of Conflict Resolution 46(1), 13-28.

Coppedge, Michael, Angel Alvarez and Claudia Maldonado. 2008. "Two Persistent Dimensions of Democracy: Contestation and Inclusiveness." Journal of Politics 70(3), 335-350.

Cullen, Hendrix. 2010. "Measuring State Capacity: Theoretical and Empirical Implications for the Study of Civil Conflict." Journal of Peace Research 47(3), 273-285.

Dafoe, Allan. 2011. "Statistical Critiques of the Democratic Peace: Caveat Emptor." American Journal of Political Science 55(2), 201-462.

Denzau, Arthur T. and Douglass C. North. 1994. "Shared Mental Models: Ideologies and Institutions." Kyklos 47(1), 3-31.

DeRouen, Karl R., and David Sobek. 2004. "The Dynamics of Civil War Duration and Outcome." Journal of Peace Research 41(3), 303-320.

Deutsch, Karl W. 1957. Political Community and the North Atlantic Area: International Organization in the Light of Historical Experience. Princeton, NJ: Princeton University Press.

Enterline, Andrew J. and Dylan Balch-Lindsay. 2008. "Third Party Intervention and the Civil War Process." Journal of Peace Research 45(3), 345-363.

Everitt, Brian S. 2005. An R and S-PLUS Companion to Multivariate Analysis. Berlin: Springer Verlag.

Farber, Henry and Joanne Gowa. 1995. "Polities and Peace." International Security 20(2), 123-146.

. 1997. "Building Bridges Abroad." Journal of Conflict Resolution 41(3), 455-456.

Fearon, James D. 1995. "Rationalist Explanations For War." International Organization 49(3), 379-414.

. 2005. "Primary Commodity Exports and Civil War." Journal of Conflict Resolution 49(4), 483-507.

Fearon, James D. and David D. Laitin. 2003. "Ethnicity, Insurgency, and Civil War." American Political Science Review 97(1), 75-90.

Gartzke, Erik. 1998. "Kant We All Just Get Along? Opportunity, Willingness, and the Origins of the Democratic Peace." American Journal of Political Science 42(1), 1-27.

. 2000. "Preferences and the Democratic Peace." International Studies Quarterly 44(2), 191-212. 
. 2007. "The Capitalist Peace." American Journal of Political Science 51(1), 166-191.

Gartzke, Erik and Joseph J. Hewitt. 2010. "International Crises and the Capitalist Peace.” International Interactions 36(2), 115-145.

Gartzke, Erik and Matthew Kroenig. 2009. "A Strategic Approach to Nuclear Proliferation." Journal of Conflict Resolution 53(2), 151-160.

Gartzke, Erik and Quan Li. 2003. "War, Peace, and the Invisible Hand: Positive Political Externalities of Economic Globalization." International Studies Quarterly 47(4), 561-586.

Gibler, Douglas M. and Meredith R. Sarkees. 2004. "Measuring Alliances: The Correlates of War Formal Interstate Alliance Dataset, 1816-2000." Journal of Peace Research 41(2), 211-222, 225.

Gilpin, Robert. 1983. War and Change in World Politics. Boston: Cambridge University Press.

Gowa, Joanne S. 1989. "Bipolarity, Multipolarity, and Free Trade." American Political Science Review 83(4), 1245-1256.

Heene, Moritz, Sven Hilbert, Clemens Draxler, Matthias Ziegler and Markus Bohner. 2011. "Masking Misfit in Confirmatory Factor Analysis by Increasing Unique Variances: A Cautionary Note on the Usefulness of Cutoff Values of Fit Indices." Psychological Methods 16(3), 319-336.

Hermann, Margaret G. and Charles W. Kegley Jr. 1995. "Rethinking Democracy and International Peace: Perspectives From Political Psychology.” International Studies Quarterly 43(2), 511-533.

Huddy, Leonie and Nadia Khatib. 2007. "American Patriotism, National Identity, and Political Involvement." American Journal of Political Science 51(1), 63-77.

$\mathrm{Hu}$, Li-tze and Peter M. Bentler. 1998. "Fit Indices in Covariance Structure Modeling: Sensitivity to Underparameterized Model Misspecification." Psychological Methods 3(4), 424-453.

Hurwitz, Jon and Mark Peffley. 1987. "How are Foreign Policy Attitudes Structured? A Hierarchical Model." American Political Science Review 81(4), 1099-1120.

Jo, Dong-Joon and Erik Gartzke. 2007. "Determinants of Nuclear Weapons Proliferation." Journal of Conflict Resolution 51(1), 167-194.

Jöreskog, Karl G. and Dag Sörbom. 2001. LISREL 8: New Statistical Features. Chicago: Scientific Software International.

Kegley, Charles W. and Eugene R. Wittkopf. 1982. American Foreign Policy: Pattern and Process. New York: St. Martin's Press.

Keohane, Robert O. 1982. "The Demand for International Regimes." 
International Organization 36(2), 325-355. . 2005. After Hegemony: Cooperation and Discord in the World Political Economy. Princeton, NJ: Princeton University Press.

Kim, Jae-On and Charles W. Mueller. 1978a. Factor Analysis: Statistical Methods and Practical Issues. Vol. 14. Beverly Hills, CA: Sage. . 1978b. Introduction to Factor Analysis: What It Is and How to Do It. Vol. 13. Beverly Hills, CA: Sage.

Leeds, Brett, Jeffery Ritter, Sara Mitchell and Andrew Long. 2002. "Alliance Treaty Obligations and Provisions, 1815-1944." International Interactions 28(3), 237-260.

Lipson, Charles. 1984. "International Cooperation in Economic and Security Affairs.” World Politics 37(1), 1-23.

Maoz, Zeev. 2000. "Alliances: The Street Gangs of World Politics-Their Origins, Management, and Consequences, 1816-1986." In John Vazquez ed., What Do We Know about War? Lanham, MD: Rowman \& Littlefield Publishers Inc., 102-144.

McDonald, Patrick J. 2009. The Invisible Hand of Peace: Capitalism, The War Machine, and International Relations Theory. Cambridge: Cambridge University Press.

. 2010. "Capitalism, Commitment, and Peace." International Interactions 36(2), 146-168.

Mitchell, Sara McLaughlin and Paul Hensel. 2007. "International Institutions and Compliance with Agreements." American Journal of Political Science 51(4), 721-737.

Mousseau, Michael. 2003. "The Nexus of Market Society, Liberal Preferences, and Democratic Peace: Interdisciplinary Theory and Evidence." International Studies Quarterly 46(4), 483-510. . 2012. "A Market-Capitalist or Democratic Peace." In John Vasquez ed., What Do We Know about War? Lanham, MD: Rowman \& Littlefield Publishers Inc., 150-175.

Naughton, Barry. 2007. The Chinese Economy: Transitions and Growth. Cambridge, MA: MIT Press.

Nye, Joseph S. 1999. "Redefining the National Interest." Foreign Affairs 78(4), 22-35.

Oneal, John R. and Bruce M. Russet. 1997. "The Classical Liberals were Right: Democracy, Interdependence, and Conflict, 1950-1985." International Studies Quarterly 41(2), 267-294.

. 1999. "Assessing the Liberal Peace with Alternative Specifications: Trade Still Reduces Conflict." Journal of Peace Research 36(4), 423- 
442.

Oneal, John R. and James Lee Ray. 1997. "New Tests of the Democratic Peace Controlling for Economic Interdependence, 1950-1985.” Political Research Quarterly 50(4), 751-775.

Polachek, Solomon W. 1980. "Conflict and Trade." Journal of Conflict Resolution 24(1), 55-78.

. 1997. "Why Democracies Cooperate More and Fight Less: The Relationship Between International Trade and Cooperation." Review of International Economics 5(3), 295-309.

Russett, Bruce M., Harvey Starr and David T. Kinsella. 2010. World Politics: The Menu for Choice. Belmont, CA: Wadsworth Publishing Co.

Russett, Bruce M. and John R. Oneal. 2001. Triangulating Peace: Democracy, Interdependence, and International Organizations. New York: Norton.

Schumacker, Randall E. and Richard G. Lomax. 2004. A Beginner's Guide to Structural Equation Modeling. New Jersey: Lawrence Erlbaum.

Souva, Mark. 2004. "Institutional Similarity and Interstate Conflict." International Interactions 30(3), 263-280.

Souva, Mark and Brandon Prins. 2006. "The Liberal Peace Revisited: The Role of Democracy, Dependence, and Development in Militarized Interstate Dispute Initiation, 1950-1999.” International Interactions 32(2), 183200.

Starr, Harvey. 1992. "Democracy and War: Choice, Learning and Security Communities.” Journal of Peace Research 29(2), 207-213.

Thies, Cameron G. 2004. "State Building, Interstate and Intrastate Rivalry: A Study of Post Colonial Developing Country Extractive Efforts, 19752000." International Studies Quarterly 48(1), 53-72.

. 2005. "War, Rivalry, and State Building in Latin America." American Journal of Political Science 49(3), 451-465. . 2007. "The Political Economy of State Building in Sub-Saharan Africa." Journal of Politics 69(3), 716-731.

Treier, Shawn and Simon Jackman. 2008. "Democracy as a Latent Variable." American Journal of Political Science 52(1), 201-217.

Voeten, Erik and Adis Merdzanovic. 2009. "United Nations General Assembly Voting Data.” Accessed at http://dvn.iq.harvard.edu/dvn/dv/Voeten/ faces/study/StudyPage.xhtml?

studyId=38311\&studyListingIndex=0_dee53f12c760141b21c251525332 (November 1, 2017).

Walt, Stephen M. 1987. The Origins of Alliances. New York: Cornell University Press. 
Walter, Barbara F. 2006. "Building Reputation: Why Governments Fight Some Separatists but not Others." American Journal of Political Science 50(2), 313-330.

Waltz, Kenneth. 1979. Theories of International Politics. Reading, MA: Addison-Wesley.

Weede, Erich. 1996. Economic Development, Social Order, and World Politics. Boulder, CO: Lynne Rienner. . 2010. "The Capitalist Peace and the Rise of China: Establishing Global Harmony by Economic Interdependence." International Interactions 36(2), 206-213.

Wendt, Alexander. 1994. "Collective Identity Formation and the International State.” American Political Science Review 45(2), 384-396.

Wendt, Alexander and Raymond Duvall. 1989. Institutions and International Order. Lexington, MA: Lexington Books.

Wright, Quincy. 1964. A Study of War. Chicago: University of Chicago Press.

[Received May 30, 2017; Revised Aug 4, 2017; Accepted Sep 14, 2017] 
